\title{
Casein infusion rate influences feed intake differently depending on metabolizable protein balance in dairy cows: A multilevel meta-analysis
}

\author{
R. Martineau, ${ }^{* 1}$ D. R. Ouellet, $†$ E. Kebreab, $\ddagger$ and H. Lapierre $†$ \\ *Valacta, Dairy Production Centre of Expertise Québec-Atlantic, Sainte-Anne-de-Bellevue, Quebec, Canada H9X 3R4 \\ †Dairy and Swine Research and Development Centre, Agriculture and Agri-Food Canada, Sherbrooke, Quebec, Canada J1M 0C8 \\ fDepartment of Animal Science, University of California, Davis 95616
}

\begin{abstract}
The effects of casein infusion have been investigated extensively in ruminant species. Its effect on responses in dry matter intake (DMI) has been reviewed and indicated no significant effect. The literature reviewed in the current meta-analysis is more extensive and limited to dairy cows fed ad libitum. A total of 51 studies were included in the meta-analysis and data were fitted to a multilevel model adjusting for the correlated nature of some studies. The effect size was the mean difference calculated by subtracting the means for the control from the casein-infused group. Overall, casein infusion [average of $333 \mathrm{~g}$ of dry matter $(\mathrm{DM}) / \mathrm{d}$; range: 91 to $1,092 \mathrm{~g}$ of $\mathrm{DM} / \mathrm{d}$ ] tended to increase responses in DMI by $0.18 \mathrm{~kg} / \mathrm{d}$ ( $\mathrm{n}=48$ studies; 3 outliers). However, an interaction was observed between the casein infusion rate (IR) and the initial metabolizable protein (MP) balance [i.e., supply minus requirements (NRC, 2001)]. When control cows were in negative MP balance $(\mathrm{n}=$ 27 studies), responses in DMI averaged $0.28 \mathrm{~kg} / \mathrm{d}$ at mean MP balance $(-264 \mathrm{~g} / \mathrm{d})$ and casein IR $(336 \mathrm{~g} / \mathrm{d})$, and a $100 \mathrm{~g} / \mathrm{d}$ increment in the casein IR from its mean increased further responses by $0.14 \mathrm{~kg} / \mathrm{d}$ (MP balance being constant), compared with cows not infused with casein. In contrast, when control cows were in positive MP balance ( $\mathrm{n}=22$ studies; 2 outliers), responses in DMI averaged $-0.20 \mathrm{~kg} / \mathrm{d}$ at mean casein IR $(339 \mathrm{~g} / \mathrm{d})$, and a $100 \mathrm{~g} / \mathrm{d}$ increment in the casein IR from its mean further decreased responses by $0.33 \mathrm{~kg} / \mathrm{d}$, compared with cows not infused with casein. Responses in milk true protein yield at mean casein IR were greater (109 vs. $65 \mathrm{~g} / \mathrm{d}$ ) for cows in negative vs. positive MP balance, respectively, and the influence of the casein IR on responses was significant only for cows in negative MP balance. A $100 \mathrm{~g} / \mathrm{d}$ increment in the casein IR from its
\end{abstract}

Received September 21, 2015.

Accepted December 18, 2015.

${ }^{1}$ Corresponding author: roger.martineau@agr.gc.ca mean increased further responses in milk true protein yield by $25 \mathrm{~g} / \mathrm{d}$, compared with cows not infused with casein. Responses in blood urea concentration increased in casein studies $(+0.59 \mathrm{mM})$ and the influence of the casein IR was greatest for cows in positive MP balance (0.26 vs. $0.11 \mathrm{~m} M$ per $100 \mathrm{~g} / \mathrm{d}$ increment). Responses in DMI were also correlated negatively with responses in blood urea concentration only for cows in positive MP balance. Together, these results suggest an association between satiety and deamination and oxidation of AA supplied in excess of requirements for cows in positive MP balance. Therefore, casein stimulated appetite in cows fed MP-deficient diets possibly via the supply of orexigenic AA or through a pull effect in response to an increased metabolic demand. Conversely, casein induced satiety in cows fed diets supplying MP in excess of requirements. Not precluding other factors involved in satiety (e.g., insulin, gut peptides), casein could have increased the supply of AA (e.g., Ser, Thr, Tyr), which might depress appetite at the brain level or increase the deamination and the oxidation of AA in oversupply in agreement with the hepatic oxidation theory.

Key words: dairy cow, meta-analysis, casein, dry matter intake, hepatic oxidation theory

\section{INTRODUCTION}

Dry matter intake regulation in ruminants is a complex issue that involves physical and chemical characteristics of dietary ingredients (e.g., NDF), and brain sensitivity to humoral signals (Ketelaars and Tolkamp, 1992; Allen, 2000; Roche et al., 2008). Some AA also appear to have the potential to regulate DMI. Feed intake was decreased in cows fed MP-deficient diets, but the supply of rumen-protected AA diminished (Lys and Met) or even corrected (His) the difference in DMI (Lee et al., 2012). Conversely, i.v. injections of nonphysiological levels of Gly, Ala, and Lys decreased feed intake in ruminants (Baile and Forbes, 1974), and Ser, Thr, and Tyr were identified as centrally acting anorexigenic signals in dairy cows (Laeger et al., 2012). 
In addition, the accumulated evidence is persuasive that the liver plays an important role in satiety. In laboratory species, the infusion of substances oxidizable in the liver (e.g., glucose) depressed food intake, whereas the infusion of substances not oxidized in the liver had no effect on food intake, even though they could be metabolized in the liver (Forbes, 1992). In a review, Friedman (1997) reported that (1) the liver ATP concentration was important in the regulation of food intake because the portal infusion of a phosphatetrapping agent (L-ethionine) triggered feeding in rats; and (2) the liver energy status was relayed to the brain feeding centers via the hepatic branch of the vagal nerve because vagotomy prevented the eating response. Therefore, the liver may play a role in the regulation of food intake because it is sensitive to anaplerotic fuels (e.g., glucogenic AA, glycerol, lactate, propionate) increasing the concentration in ATP.

The involvement of substrate oxidation in DMI regulation is a relatively new concept in dairy cattle and was termed the hepatic oxidation theory (HOT) of the control of food intake (Allen et al., 2009). Application of this concept to dairy cows is appealing because it integrates the effects of various fuels (e.g., nonesterified fatty acids, glucogenic AA) and physiological states on feeding behavior (Allen et al., 2005; Allen, 2014). However, the demonstration of the HOT concept in ruminants presents a challenge in feeding experiments because ruminal fermentation affects the type and pattern of absorbed fuels (Allen et al., 2009). Moreover, responses in DMI can be subtle and difficult to demonstrate in dairy cows because most of the studies are conducted on a limited number of animals and lack sufficient statistical power.

In contrast to feeding studies, abomasal or duodenal infusion of a protein source has a minimal effect on rumen metabolism and dietary characteristics besides total energy and MP supply (Faverdin, 1999; Chamberlain and Yeo, 2003). Therefore, a review based on infusion studies appears ideal to evaluate responses in DMI to a known increment in MP. Casein and other protein sources have been infused over the last 4 decades in dairy cows, and so far little or no effect on DMI was reported (see review: Faverdin, 1999; Allen, 2000; Patton et al., 2015). However, conclusions from these reviews need to be revisited with updated literature, using new statistical tools available for meta-analysis.

The current meta-analysis reviewed the effect of casein infusion on responses in DMI in cows fed ad libitum with a special emphasis on the influence of the casein infusion rate on responses in DMI when the initial balance of MP was either negative or positive. It was hypothesized that the rate of casein infusion nega- tively influences responses in DMI when cows are in positive MP balance due to increased oxidation of AA in oversupply, in line with the HOT concept. Therefore, the objectives of the current meta-analysis were to (1) report a new methodological approach, taking into account the hierarchical nature of studies in the data set, (2) determine the effect of CN on responses in DMI in cows fed ad libitum, and (3) explore the influence of the $\mathrm{CN}$ infusion rate and other factors that could explain part of the heterogeneity.

\section{MATERIALS AND METHODS}

\section{Data Sources}

The Scopus online database was searched in February 2015 for studies where casein was infused postruminally in dairy cows with the terms: "casein or caseinate", "abomasal or duodenal", and "cow* or dairy". To be included in the meta-analysis, the studies were required to (1) include a casein (CAS) treatment consisting of CN infused postruminally; (2) include a control (CTL) treatment consisting of water or saline also infused postruminally (plus a substrate if infused at the same rate in the CAS treatment); (3) report the sample size (n) and a measure of variance; (4) feed the forage or complete ration ad libitum; (5) report information on feed intake, feed ingredients, or ration composition; and (6) be published in English or French.

Reasons for the exclusion of studies were (1) use of CN hydrolysate (Seymour et al., 1990) or formaldehyde-treated CN (Broderick et al., 1972), (2) composition of diet not being similar in CTL and CAS treatments (Derrig et al., 1974; Rogers et al., 1984; Cant et al., 1991), (3) unsuitable randomization (Istasse et al., 1986), (4) absence of negative or suitable controls (Choung and Chamberlain, 1993c; Røjen et al., 2013), and (5) extremely low level of estimated MP supply in control cows (<800 g/d, Rogers et al., 1979). In Schwab et al. (1992), DL-Met was not infused with CN, but the DL-Met infusion was accepted as the negative control because DL-Met was not first-limiting compared with L-Lys. The final data set contained 51 studies from 26 manuscripts. A summary description of studies included in the data set is given in Table 1 .

\section{Data Extraction and Calculations}

The current meta-analysis was conducted on mean DMI in CTL and CAS treatment groups. The mean DMI in CAS treatment did not include the DM from the casein infusate. Animal and dietary variables were evaluated for their influence on responses in DMI to ca- 


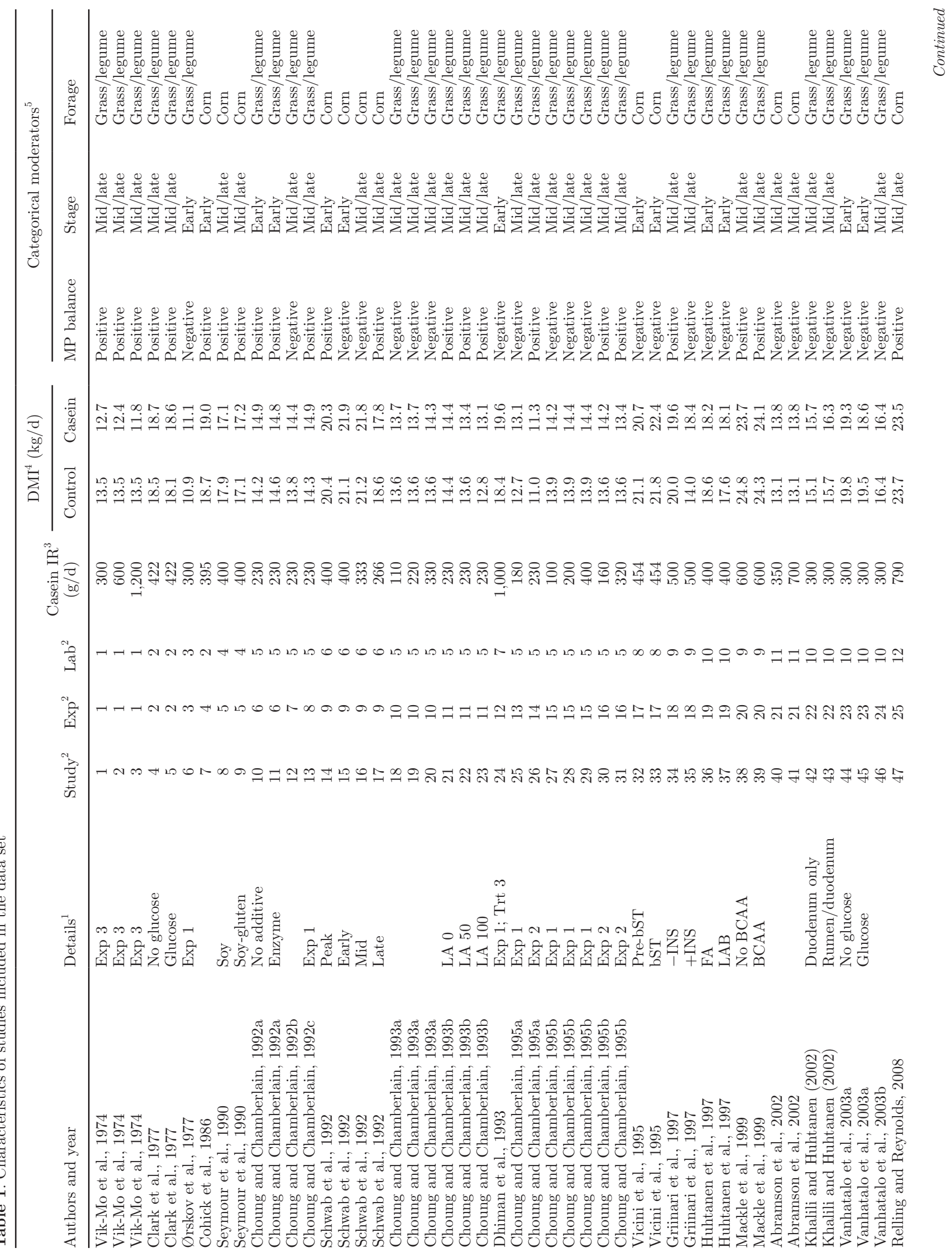


sein infusion. Continuous variables included rate of $\mathrm{CN}$ infusion ( $\mathrm{kg}$ of $\mathrm{DM} / \mathrm{d})$, ration parameters, and nutritional balances (Allen, 2000; Hristov et al., 2004). Unless indicated otherwise in the manuscript, the amount of $\mathrm{CN}$ infused was assumed to be reported on an as-is basis and to contain 91.0\% DM (NRC, 2001). The CTL and CAS rations were reconstituted as described in Martineau et al. (2011). The following parameters from the control ration were included in the data set: $\mathrm{CP}(\%$ $\mathrm{DM}), \mathrm{RDP}(\% \mathrm{DM}$ and \% $\mathrm{CP}$ ), proportion of concentrate (\%), NDF (\% DM), forage NDF (\% DM; fNDF), $\mathrm{ADF}(\% \mathrm{DM})$, ether extract (\% DM; EE), NFC (\% $\mathrm{DM}), \mathrm{TDN}(\% \mathrm{DM})$, and $\mathrm{NE}_{\mathrm{L}}(\mathrm{Mcal} / \mathrm{kg})$.

Nutritional balances (dietary supply minus requirements; NRC, 2001) of control cows in RDP ( $\mathrm{kg}$ of $\mathrm{DM} / \mathrm{d}), \mathrm{MP}(\mathrm{kg}$ of $\mathrm{DM} / \mathrm{d})$, and $\mathrm{NE}_{\mathrm{L}}(\mathrm{Mcal} / \mathrm{d})$ were determined using the following default values if necessary: DIM $=100 \mathrm{~d}$; milk NPN concentration $=5 \%$; milk fat $=3.42 \%$; milk lactose $=4.60 \%$. Body weight was missing in 16 studies and assumed to be 602 or $564 \mathrm{~kg}$ for North American cows or other, respectively (Huhtanen and Hristov, 2009).

Three categorical variables were tested: (1) stage of lactation at the start of the experiment (early $\leq 100$ DIM; mid/late >100 DIM), (2) type of forage (grass/ legume: grass/legume/mixed hay or silage or straw; corn silage), and (3) MP balance (negative or positive) of control cows. Stage of lactation was missing in Clark et al. (1977), but the information was obtained from Istasse et al. (1986). Stage of lactation was not reported in Vik-Mo et al. (1974) and Choi et al. (2013), but cows were assumed to be in mid/late lactation based on milk yield $(\leq 18 \mathrm{~kg} / \mathrm{d})$. Note that MP balance was tested as a categorical variable only if the interaction between MP balance values and the $\mathrm{CN}$ infusion rate was significant (see below).

Dispersion Measures. Dispersion measures were converted into standard deviation when aggregating data. For studies reporting standard error of the mean (or standard error), standard deviation was calculated by multiplying standard error of the mean by $\sqrt{n}$; and for studies reporting the standard error of the difference between any 2 means, standard deviation was calculated by multiplying standard error of the difference by $\sqrt{n} / \sqrt{2}$. A mixed procedure was used in 6 studies and the same conversion factors were applied. In experiments using a factorial arrangement of treatments, the dispersion measure of the interaction term was selected to calculate standard deviation.

Effect Size and Statistical Weight. The effect size for statistical analyses was the mean difference (MD) in DMI $(\mathrm{kg} / \mathrm{d})$ :

$$
\text { Effect size: } \mathrm{MD}=\mathrm{CAS}-\mathrm{CTL} \text {, }
$$


calculated with the escalc function of the metafor package (version 1.9-5) in $\mathrm{R}$ (version 3.1.2, $\mathrm{R}$ Foundation for Statistical Computing, Vienna, Austria; R Development Core Team. 2008). In metafor, more precise studies with a larger sample size or low SD have more of an effect on results. The statistical weight was the inverse of variance corrected by the addition of $\sigma^{2}$ (Viechtbauer, 2010).

Forest Plot. A forest plot was constructed using standardized mean difference (SMD) values calculated with the escalc function of metafor by dividing $\mathrm{MD}$ values by their pooled standard deviation $\left(\mathrm{SD}_{\text {pooled }}\right)$ adjusted for the positive bias associated with small samples (Hedges and Olkin, 1985):

$$
\begin{aligned}
\mathrm{SD}_{\text {pooled }} & =\sqrt{\left[\mathrm{SD}_{1}^{2}\left(n_{1}-1\right)+\mathrm{SD}_{2}^{2}\left(n_{2}-1\right)\right] /\left[n_{1}+n_{2}-2\right]}, \\
\mathrm{SMD} & =\mathrm{MD} / \mathrm{SD}_{\text {pooled }} \times\left\{1-3 /\left[4 \times\left(n_{1}+n_{2}\right)-9\right]\right\},
\end{aligned}
$$

where $n_{1}$ and $n_{2}$ refer to the number of replica for CAS and CTL treatments, respectively. Therefore, SMD values in the forest plot took into account the variability in each study.

\section{Statistical Models}

Multilevel Model. Use of the metafor package in R has been described by Appuhamy et al. (2013) and Bougouin et al. (2014). The principles behind the metafor package are the same as the methodology proposed by St-Pierre (2001). In contrast with previous meta-analyses in $\mathrm{R}$, a multilevel model was used to recognize the hierarchical nature of studies included in the data set (Konstantopoulos, 2011; Viechtbauer, 2014). For example, the current meta-analysis included effect sizes created from (1) graded CN infusion rates compared with a common control (e.g., Vik-Mo et al., 1974), (2) repeated measurements on the same cows throughout lactation (Larsen et al., 2014), (3) studies from a factorial arrangement of treatments (e.g., Clark et al., 1977), and (4) studies conducted either by the same authors or at the same research center (e.g., Hannah Research Institute, UK). Indeed, the underlying true effects are expected to be more similar for such studies, in violation of the principle that studies should be statistically independent in a meta-analytic review (Wang and Bushman, 2007).

To account for this form of dependency or correlation among studies, 2 grouping variables were created to cluster studies originating from the same experiment and experiments originating from the same laboratory (Table 1). The random effects of study, experiment, and laboratory were specified as a list of one-sided formulas in the random argument of the rma.mv function of metafor. The REML method was used and the effect sizes with the same level within each grouping variable received the same random effect; otherwise, effect sizes were assumed to be independent (Viechtbauer, 2010). The variance component $\left(\sigma^{2}\right)$ was divided into 3 parts to indicate where most of the variation lied, that is, between (1) studies nested within experiments, (2) experiments nested within laboratories, and (3) laboratories.

Global Effect Size and Meta-Regression. The global effect size summarizes the effect of CN infusion on responses in DMI across studies under the assumption of perfect control conditions. In a meta-regression, the true effect size is a function of both the fixed effect of moderators and the random effects of study and clustering variables plus a certain amount of residual heterogeneity. Meta-regressions explain part of the heterogeneity, improve conclusions, and may identify important new research topics.

All continuous moderators were centered on their mean. Centering moderators does not change the regression coefficients, but the intercept will be the global effect size estimate at the mean value of all the moderators included in the model (and not at the zero value of moderators if not centered). Centering moderators allows the interpretation of regression coefficients in terms of change in the response in DMI $(\mathrm{kg} / \mathrm{d})$ for a 1 unit change in a moderator from its mean (all other moderators being constant).

The mod argument of the rma.mv function of metafor (REML method) was used to test the meta-regressions. In a first step, the influence of each moderator was evaluated separately; however, for a continuous moderator, the meta-regression included the quadratic term and the interaction between each categorical moderator (i.e., stage of lactation and type of forage) and the continuous moderator. The meta-regression was reduced by removing not significant $(P>0.10)$ variables. In a second step, a multivariate meta-regression included all significant $(P \leq 0.10)$ moderators and interaction terms, and the infusion rate of $\mathrm{CN}$ which was forced into the meta-regression because it was the variable of interest. A backward stepwise selection procedure was used to eliminate (one at a time) not significant variables and the multivariate meta-regression was further reduced to the smallest number of relevant variables (including the $\mathrm{CN}$ infusion rate).

Meta-regressions were compared using the log-likelihood ratio test (LRT; $P \leq 0.10$ ) of the anova function of metafor or the Akaike information criterion (AIC) of the fitstats function of metafor. The LRT test was used to compare hierarchical meta-regressions with different number of variables (maximum likelihood 
method). Alternatively, the AIC was used to compare meta-regressions with the same number of moderator and the same studies.

Outlier Management. Sensitivity analyses were conducted to detect effect sizes exerting substantial influence on results (Viechtbauer and Cheung, 2010). Graphical assessment of all relationships (response and absolute values) was carried out with Minitab (version 16.2.1, 2010, Minitab Inc., State College, PA). The influence function of metafor was also used to detect outliers based on the rma function of metafor (not yet available with rma.mv). Outliers were removed from the data set if they induced a qualitative change on coefficient terms or $P$-values. Outliers were not removed permanently from the data set because their effect could vary depending on moderators included in the meta-regression.

Tests for Residual Heterogeneity. A significant heterogeneity statistic indicates that the variability in the observed effect sizes (and not accounted for by the moderators in a meta-regression) is larger than ex- pected based on the sampling variability and the given covariances among the sampling errors (Hedges and Olkin, 1985; Viechtbauer, 2015).

Animal Care and Use Committee approval was not required for this meta-analytic review because all data were obtained from the literature.

\section{RESULTS AND DISCUSSION}

The current meta-analysis was conducted on studies where sodium, calcium, or lactic CN was infused postruminally in lactating dairy cows fed ad libitum. A total of 51 studies met the inclusion criteria either from Europe $(\mathrm{n}=32)$, North America $(\mathrm{n}=16)$, or other continents $(\mathrm{n}=3)$. The rate of $\mathrm{CN}$ infusion $(\mathrm{g} / \mathrm{d}$; as-is basis), DMI ( $\mathrm{kg} / \mathrm{d})$ for CTL and CAS treatments, and the corresponding SMD value with its $95 \%$ of CI (whiskers) are presented in a forest plot along with the author(s) and year arranged in a chronological order (Figure 1). Approximately $60 \%$ of studies showed a positive effect of $\mathrm{CN}$ infusion on DMI, but this effect

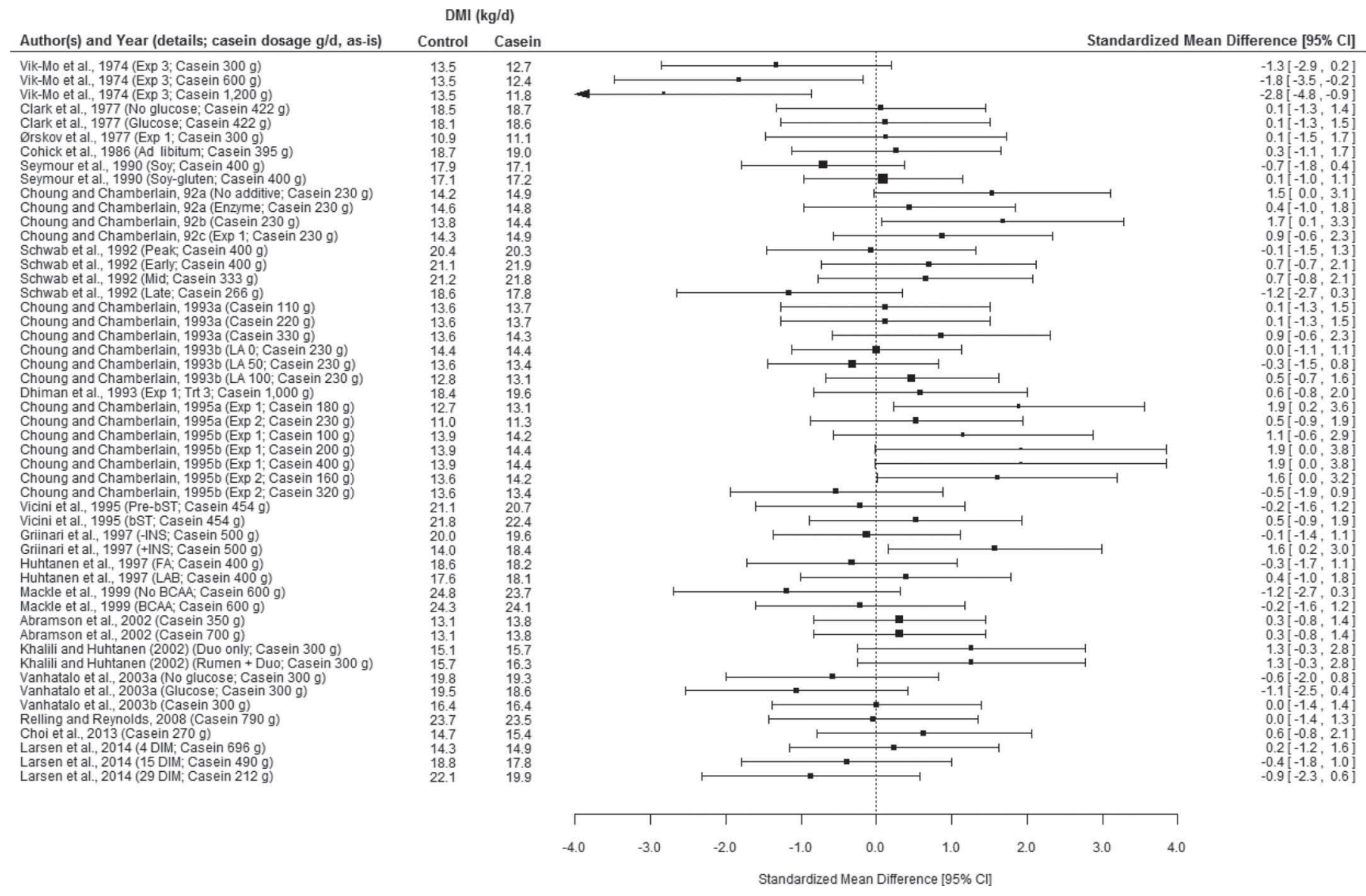

Figure 1. Forest plot showing mean DMI $(\mathrm{kg} / \mathrm{d})$ in the control and casein treatments along with the standardized mean difference (boxes) and $95 \%$ of CI (whiskers). The dotted line represents a zero standardized mean difference. LA = lactic acid; INS = insulin; FA = formic acid; $\mathrm{LAB}=$ lactic acid bacteria; Duo = duodenum; BCAA = branched-chain AA. 
Table 2. Description of cow- and ration-associated factors separated by MP balance category ${ }^{1}$

\begin{tabular}{|c|c|c|c|c|c|c|c|c|}
\hline Item & \multicolumn{4}{|c|}{ Negative MP balance $(\mathrm{n}=27)$} & \multicolumn{4}{|c|}{ Positive MP balance $(\mathrm{n}=24)$} \\
\hline Casein infusion rate (g of DM/d) & 336 & 175.4 & 91 & \multicolumn{3}{|c|}{ Cow-associated factor ${ }^{2}$} & 146 & 1,092 \\
\hline DIM (d) & 100 & 56.7 & 4 & 210 & 119 & 43.6 & 28 & 203 \\
\hline DMI (kg/d) & 16.4 & 3.36 & 10.9 & 22.1 & 16.6 & 3.87 & 11.0 & 24.8 \\
\hline Milk yield (kg/d) & 24.7 & 9.10 & 12.1 & 43.4 & 21.7 & 6.89 & 10.7 & 37.4 \\
\hline Blood urea $(\mathrm{m} M)$ & $3.6^{* *}$ & 0.94 & 2.0 & 5.5 & $6.0^{* *}$ & 3.40 & 2.0 & 10.3 \\
\hline \multicolumn{9}{|l|}{ Ration-associated factor ${ }^{3}$} \\
\hline MP supply $(\mathrm{g} / \mathrm{d})$ & $1,453^{*}$ & 397.4 & 867 & 2,382 & $1,733^{*}$ & 511.0 & 1,143 & 2,924 \\
\hline MP requirements $(\mathrm{g} / \mathrm{d})$ & 1,718 & 501.3 & 1,116 & 2,656 & 1,595 & 387.6 & 930 & 2,277 \\
\hline MP balance $(\mathrm{g} / \mathrm{d})$ & $-264^{* * *}$ & 198.3 & -751 & -21.3 & $139^{* * *}$ & 178.9 & 17 & 647 \\
\hline $\mathrm{NE}_{\mathrm{L}}(\mathrm{Mcal} / \mathrm{kg}$ of $\mathrm{DM})$ & $1.52^{* *}$ & 0.081 & 1.26 & 1.70 & $1.58^{* *}$ & 0.075 & 1.48 & 1.74 \\
\hline $\mathrm{RDP}(\%$ of DM) & 11.0 & 1.32 & 9.6 & 13.7 & 10.7 & 2.02 & 6.6 & 16.8 \\
\hline RUP ( $\%$ of DM) & $4.23^{* * *}$ & 1.108 & 2.69 & 6.40 & $5.81^{* * *}$ & 1.196 & 3.69 & 7.62 \\
\hline $\operatorname{RDP}(\%$ of $\mathrm{CP})$ & $72^{* * *}$ & 6.4 & 60 & 83 & $65^{* * *}$ & 7.8 & 48 & 74 \\
\hline RDP balance $(\mathrm{g} / \mathrm{d})$ & 211 & 255.2 & -75.1 & 775 & 92 & 339.6 & -578 & 1,112 \\
\hline NDF ( $\%$ of DM) & $40 \dagger$ & 5.0 & 30 & 47 & $37 \dagger$ & 6.7 & 28 & 48 \\
\hline Forage NDF ( $\%$ of DM) & 33 & 7.2 & 22 & 46 & 30 & 7.6 & 18 & 40 \\
\hline $\mathrm{ADF}(\%$ of $\mathrm{DM})$ & $25 \dagger$ & 5.7 & 17 & 41 & $23 \dagger$ & 4.2 & 16 & 29 \\
\hline Ether extract (\% of DM) & $2.8^{* *}$ & 0.66 & 1.8 & 4.0 & $3.3^{* *}$ & 0.48 & 2.7 & 4.2 \\
\hline $\mathrm{NFC}(\%$ of DM) & 38 & 5.0 & 29 & 46 & 39 & 6.5 & 22 & 48 \\
\hline TDN (\% of DM) & $66^{*}$ & 4.1 & 54 & 73 & $69^{*}$ & 3.8 & 61 & 74 \\
\hline
\end{tabular}

${ }^{1}$ Mean, SD, minimum (min), and maximum (max) values are reported for each parameter and separated by MP balance category (refer to Table 1). All values were calculated for the control treatment, except the $\mathrm{CN}$ infusion rate. Means between negative and positive MP balances were separated by Tukey-Kramer test (1-way ANOVA analysis).

${ }^{2}$ Number of studies $=27$ and 24 for negative and positive MP balance, respectively, except for DIM ( $\mathrm{n}=24$ and 17 studies), milk lactose \% ( $\mathrm{n}$ $=21$ and 15 studies $)$, and blood urea concentration $(\mathrm{n}=16$ and 10 studies $)$.

${ }^{3}$ Information on feed ingredient composition was not reported in 7 studies. Information on ration composition was not reported in 1 study but was calculated from feed ingredient composition. Supply in MP and balances in RDP, MP, and $\mathrm{NE}_{\mathrm{L}}$ were calculated according to NRC (2001).

${ }^{* * *} P \leq 0.001 ;{ }^{* *} P \leq 0.01 ;{ }^{*} P \leq 0.05 ; \dagger P \leq 0.10$.

was significant only in few studies based on SMD $95 \%$ CI limits.

\section{Description of the Data Set}

Twice as many studies were found for mid/late versus early lactating cows (35 vs. 16), and most cows in early lactation were in negative MP balance (Pearson chi-square, $P=0.03$; Table 1 ). Similarly, twice as many studies were found for cows fed grass/legume- versus corn silage-based diets, but the meta-design was balanced (Pearson chi-square, $P=0.51$ ).

The studies reviewed in the current meta-analysis covered a large variety of feeding conditions. Inclusion percentages of grass/legume forages, corn silage, grain, and protein sources averaged $62 \pm 14.6 \%$ (range: 34 to $100 \%$ ), $12 \pm 20.8 \%$ (range: 0 to $74 \%$ ), $27 \pm 12.5 \%$ (range: 0 to $57 \%$ ), and $8 \pm 6.6 \%$ (range: 0 to $36 \%$ ), respectively. All-forage diets were fed in Dhiman et al.
(1993) and Khalili and Huhtanen (2002), and protein sources were not fed in Ørskov et al. (1977), Choung and Chamberlain (1993a), Huhtanen et al. (1997), and Abramson et al. (2002). Added urea supplied $10 \%$ of total N intake in Vik-Mo et al. (1974) and about 30\% of total N intake in Ørskov et al. (1977) and Abramson et al. (2002).

In Table 2, cow- and ration-associated parameters are summarized by MP balance category (negative or positive). The infusion rate of $\mathrm{CN}$ averaged $351 \pm 192.4$ $\mathrm{g}$ of $\mathrm{DM} / \mathrm{d}$ and was greater than $500 \mathrm{~g}$ of $\mathrm{DM} / \mathrm{d}$ in 8 studies (Table 1); therefore, more research is required to increase the accuracy of results at high infusion rate of CN. Cow-associated factors did not differ between MP balance categories, except for blood urea concentration, which was $67 \%$ higher $(P=0.01)$ for cows in positive MP balance (Table 2). Estimated MP requirements did not differ between MP balance categories, but estimated MP supply was $16 \%$ lower $(P=0.03)$ for cows 
in negative MP balance. Supply in $\mathrm{NE}_{\mathrm{L}}$ did not differ between MP balance categories, but $\mathrm{NE}_{\mathrm{L}}$ requirements tended $(P=0.07)$ to be $11 \%$ greater for cows in negative MP balance (Table 2). Although the meta-design was balanced between types of forage and balances in $\mathrm{MP}$, some differences (i.e., NDF, ADF, and TDN) were related to the inclusion of 3 all-forage studies in the negative MP balance category (Table 2).

\section{Effect of CN on Responses in DMI (All Studies)}

Global Effect Size. The effect of CN infusion on responses in DMI differed whether the meta-analysis was conducted on all studies or after the removal of 3 outlying studies from Vik-Mo et al. (1974). Before removal of outliers, the heterogeneity was highly significant $(Q$ $=110 ; P<0.001)$ and $85 \%$ of the total heterogeneity was observed at the laboratory level (data not shown). After removal of outliers, the global effect size estimate indicated that the infusion of $\mathrm{CN}$ (mean $=333 \mathrm{~g}$ of $\mathrm{DM} / \mathrm{d})$ tended $(P=0.10)$ to increase responses in DMI by $0.18 \mathrm{~kg} / \mathrm{d}$. The heterogeneity was reduced by half $(Q$ $=60 ; P=0.10$ ), mostly at the laboratory level (data not shown). The forest plot clearly showed that the studies from Vik-Mo et al. (1974) appeared discordant compared with the other studies in the data set (Figure 1). Our results differ from those reported in Faverdin (1999) and Allen (2000), but the current review is more exhaustive (e.g., all the research conducted at the Hannah Research Institute is included). Clark (1975) reported that CN infusion increased DMI in Spechter (1972), but data from this early study were not available.

Meta-Regressions. Interactions between categorical and continuous moderators were not significant. When analyzed separately, stage of lactation and type of forage had no influence on responses in DMI, but several continuous moderators did. The infusion rate of $\mathrm{CN}$ had no influence on responses in DMI. Fiber and energy moderators had an opposite influence on responses in DMI: the influence of NDF, fNDF, and ADF was positive $(P \leq 0.001$, data not shown $)$ and that of $\mathrm{EE}, \mathrm{NFC}, \mathrm{TDN}$, and $\mathrm{NE}_{\mathrm{L}}$ was negative $(P \leq$ 0.022 , data not shown).

A quadratic relationship was observed for the influence of MP balance $(\mathrm{kg} / \mathrm{d})$ and $\mathrm{NE}_{\mathrm{L}}$ balance $(\mathrm{Mcal} / \mathrm{d})$ on responses in DMI:

$$
\begin{gathered}
\text { Responses in DMI }(\mathrm{kg} / \mathrm{d})=-0.26( \pm 0.513) \\
\times \mathrm{MP} \text { balance }-3.15( \pm 1.22) \times \mathrm{MP} \text { balance } \\
\times \mathrm{MP} \text { balance }+0.27( \pm 0.255) \\
\left(\mathrm{AIC}=108.0 ; \sigma^{2}=0.414 ; \mathrm{n}=51\right) ; \\
\text { Responses in DMI }(\mathrm{kg} / \mathrm{d})=-0.07( \pm 0.041) \\
\times \mathrm{NE}_{\mathrm{L}} \text { balance }-0.015( \pm 0.0089) \times \mathrm{NE}_{\mathrm{L}} \text { balance } \\
\times \mathrm{NE}_{\mathrm{L}} \text { balance }+0.25( \pm 0.236) \\
\left(\mathrm{AIC}=106.6 ; \sigma^{2}=0.276 ; \mathrm{n}=51\right) .
\end{gathered}
$$

The $P$-value of the quadratic term was 0.010 and 0.098 for the former and latter, respectively. The quadratic relationship suggested a positive slope when balance values were negative, and a negative slope when balance values were positive. Collectively, these results suggest that responses in DMI were influenced by the composition of the diet and the nutritional status of control cows.

Multivariate Meta-Regressions. Although the AIC value indicated a better fit for the meta-regression with $\mathrm{NE}_{\mathrm{L}}$ balance, multivariate meta-regressions were developed to the balance in MP because the quadratic term was highly significant as shown above. It was anticipated that some moderators could capture the variability associated with MP balance $\times$ MP balance.

\begin{tabular}{|c|c|c|c|c|c|c|c|c|c|}
\hline Item & $\mathrm{NDF}$ & fNDF & $\mathrm{ADF}$ & $\mathrm{EE}$ & $\mathrm{NFC}$ & TDN & $\mathrm{NE}_{\mathrm{L}}$ & MP balance & $\mathrm{NE}_{\mathrm{L}}$ balance \\
\hline
\end{tabular}

Two multivariate meta-regressions were tested: (1) rate of $\mathrm{CN}$ infusion $\times \mathrm{MP}$ balance and (2) rate of $\mathrm{CN}$ infusion, MP balance, and MP balance $\times$ MP balance. The multivariate meta-regressions also included NDF,

Table 3. Correlation coefficients showing the relationships between the casein infusion rate (IR; $\mathrm{kg}$ of DM/d), the dietary contents (\% DM) in $\mathrm{NDF}$, forage $\mathrm{NDF}$ (fNDF), $\mathrm{ADF}$, ether extract $(\mathrm{EE}), \mathrm{NFC}, \mathrm{TDN}$, and in $\mathrm{NE}_{\mathrm{L}}(\mathrm{Mcal} / \mathrm{kg}$ ); and the nutritional balances (supply minus requirements; $\mathrm{NRC}, 2001)$ in $\mathrm{MP}(\mathrm{kg}$ of $\mathrm{DM} / \mathrm{d})$ and $\mathrm{NE}_{\mathrm{L}}(\mathrm{Mcal} / \mathrm{d})$ in control cows 
Table 4. Meta-regressions showing the influence of moderators on responses in DMI $(\mathrm{kg} / \mathrm{d})$ to CN infusion in dairy cows fed ad libitum ${ }^{1}$

\begin{tabular}{|c|c|c|c|c|c|c|c|c|}
\hline Item $^{2}$ & \multicolumn{2}{|c|}{ Effect size } & \multicolumn{5}{|c|}{ Heterogeneity } & Outliers $^{3}$ \\
\hline \multicolumn{9}{|l|}{ All studies $(\mathrm{n}=51)$} \\
\hline Intercept & $0.01 \pm 0.095$ & 0.94 & $0.02(14)$ & $0.00(27)$ & $0.02(51)$ & $52(\mathrm{df}=46)$ & 0.26 & \\
\hline $\mathrm{NE}_{\mathrm{L}}(\mathrm{Mcal} / \mathrm{kg})$ & $-4.13 \pm 1.097$ & $<0.01$ & & & & & & \\
\hline MP balance $(\mathrm{kg} / \mathrm{d})$ & $0.14 \pm 0.404$ & 0.73 & & & & & & \\
\hline \multicolumn{9}{|l|}{ Meta-regression $2^{4}$} \\
\hline Intercept (negative MP balance) & $0.39 \pm 0.141$ & $<0.01$ & $0.04(14)$ & $0.00(27)$ & $0.00(51)$ & $50(\mathrm{df}=47)$ & 0.34 & \\
\hline Intercept (positive MP balance) & $-0.27 \pm 0.125$ & 0.03 & & & & & & \\
\hline MP balance (negative): casein IR & $1.00 \pm 0.673$ & 0.14 & & & & & & \\
\hline MP balance (positive): casein IR & $-2.00 \pm 0.462$ & $<0.01$ & & & & & & \\
\hline \multicolumn{9}{|c|}{$\begin{array}{l}\text { 1) Studies with negative MP balance } \\
(\mathrm{n}=27)\end{array}$} \\
\hline \multicolumn{9}{|l|}{ Meta-regression $4^{5}$} \\
\hline Intercept & $-0.20 \pm 0.117$ & 0.08 & $0.01(8)$ & $0.00(14)$ & $0.00(22)$ & $17(\mathrm{df}=20)$ & 0.65 & 1,3 \\
\hline Casein IR (kg of DM/d) & $-3.34 \pm 0.809$ & $<0.01$ & & & & & & \\
\hline
\end{tabular}

${ }^{1}$ Each meta-regression adjusted data for the random effects of studies nested within experiments (Exp), experiments nested within laboratories (Lab), and laboratories (refer to the text and Table 1). Continuous moderators were centered on their mean (from the control treatment). The variance and the number of levels (in parentheses) are reported for Lab, Exp, and Study. The residual heterogeneity statistic ( $Q E$-test) and its $P$-value are reported for each model.

${ }^{2}$ Meta-regressions were conducted on all studies and on studies where control cows were in negative or positive MP balance according to NRC (2001; refer to Table 1). MP balance = supply minus requirements in kilograms per day (DM basis).

${ }^{3}$ Studies (refer to Table 1) deemed outliers and not included in the model.

${ }^{4}$ Intercepts were different: $P<0.001$. MP balance category $\times$ casein infusion rate (IR) had a $P$-value $<0.001$.

${ }^{5} \mathrm{MP}$ balance was not included in meta-regression 4 because $P=0.20$. Average casein $\mathrm{IR}=0.339 \mathrm{~kg}$ of $\mathrm{DM} / \mathrm{d}(\mathrm{n}=22 \mathrm{studies})$.

$\mathrm{EE}$, and $\mathrm{NE}_{\mathrm{L}}$. Among significant fiber moderators, NDF was chosen over fNDF because its AIC value was lowest, and among significant energy moderators, $\mathrm{NE}_{\mathrm{L}}$ was chosen in lieu of NFC and TDN because its correlation with NDF was lowest $(\mathrm{r}=-0.72$; Table 3$)$. Moderators $\mathrm{EE}$ and NDF were not significant and deleted from both multivariate meta-regressions. The AIC and $Q E-$ test values indicated that the first multivariate metaregression explained more variability compared with the second: 99.3 and 51.9 versus 100.8 and 53.7, respectively. The first multivariate meta-regression could not be reduced to less number of relevant variables based on LRT analyses and is presented as meta-regression 1 in Table 4.

\section{Effect of CN on Responses in DMI (by MP Balance Categories)}

Meta-Regression 2. An interaction was observed $(P=0.03)$ between MP balance values and the $\mathrm{CN}$ infusion rate (meta-regression 1, Table 4). Therefore, a new meta-regression was developed to test the interac- tion between the rate of $\mathrm{CN}$ infusion and the categories of MP balance (negative or positive; meta-regression 2, Table 4). Again, the interaction was significant ( $P$ $<0.001$; Table 4) and the relationship is depicted in Figure 2, taking into account the relative statistical weight of each study. Note that the removal of the apparent outlier (study 3; Table 1) was tested and did not qualitatively change the results (data not shown).

Studies with Negative MP Balance. The global effect size estimate indicated that the infusion of $\mathrm{CN}$ $($ mean $=336 \mathrm{~g}$ of DM/d) increased $(P<0.001)$ responses in DMI by $0.39 \mathrm{~kg} / \mathrm{d}$ (data not shown). Responses in DMI averaged $0.28 \mathrm{~kg} / \mathrm{d}$ at mean $\mathrm{CN}$ infusion rate and a 1 unit $(\mathrm{kg}$ of $\mathrm{DM} / \mathrm{d})$ increase in the $\mathrm{CN}$ infusion rate increased $(P=0.044)$ further responses by $1.4 \mathrm{~kg} / \mathrm{d}$ (MP balance being constant), compared with cows not infused with CN (meta-regression 3; Table 4).

In the current meta-analysis, responses in milk true protein yield (MTPY) to CN infusion differed $(P=$ 0.003 ) between negative and positive MP balance. Responses in MTPY averaged 109 and $65 \mathrm{~g} / \mathrm{d}$ at mean infusion rate of $\mathrm{CN}$ for cows in negative and positive MP 
balance, respectively. For cows in negative MP balance, 1 unit $(\mathrm{kg} / \mathrm{d})$ increase in the $\mathrm{CN}$ infusion rate increased $(P<0.001)$ further responses by $252 \mathrm{~g} / \mathrm{d}$, compared with cows not infused with $\mathrm{CN}$. In contrast, the infusion rate had no influence on responses in MTPY for cows in positive MP balance (data not shown). Cows were in negative MP balance in Khalili and Huhtanen (2002) and Faverdin et al. (2003). In these studies, a MP supply not only increased milk protein yield and DMI by modified the feeding behavior. In Khalili and Huhtanen (2002), CN increased DMI $(+4 \%)$, the eating time per meal $(+17 \%)$, and the total chewing time $(+6 \%)$. In Faverdin et al. (2003), partially hydrolyzed isolates of soybean protein enriched with AA increased DMI $(+9 \%)$, decreased the number of meals per day $(-13 \%)$, but cows ate more DM per meal $(+27 \%)$ and per unit of time $(+16 \%)$. Taken together, these results suggest that cows in negative MP balance are able to adapt their feeding behavior to face the increased energy demand (i.e., a pull effect on DMI). Alternatively, Lee et al. (2012) hypothesized that milk yield is increased as a consequence of increased DMI. Milk yield and DMI were decreased in MP-deficient diets and the supply of rumen-protected AA diminished (Lys and Met) or even corrected (His) the difference in DMI and milk yield (Lee et al., 2012). Therefore, CN infusion might also increase DMI by supplying orexigenic AA in dairy cows.

Studies with Positive MP Balance. The global effect size estimate was not different from zero. Responses in DMI averaged $-0.2 \mathrm{~kg} / \mathrm{d}$ at mean CN infusion rate $(339 \mathrm{~g}$ of $\mathrm{DM} / \mathrm{d})$ and a 1 unit $(\mathrm{kg}$ of $\mathrm{DM} / \mathrm{d})$ increase in $\mathrm{CN}$ infusion rate decreased $(P<0.001)$ further responses by $3.34 \mathrm{~kg} / \mathrm{d}$, compared with cows not infused with CN (meta-regression 4; Table 4).

Factors inducing satiety have been reviewed (Ingvartsen and Andersen, 2000; Allen et al., 2009; Allen, 2014). Because CN infusion has minimal effect on rumen metabolism, satiety could involve brain sensitivity to humoral signals (e.g., gut peptides, pancreatic hormones), but results are not yet conclusive in dairy cows (Relling and Reynolds, 2008; Relling et al., 2010). Insulin and glucagon are considered important satiety hormones in nonruminants (Woods et al., 2006), but the role of insulin on the regulation of DMI is less clear in dairy cows. Many AA, especially the branched-chain AA, are insulin secretagogues in ruminants (Kuhara et al., 1991). Accordingly, CN increased plasma concentration of branched-chain AA, but with no effect on DMI (Huhtanen et al., 1997; Miettinen and Huhtanen,

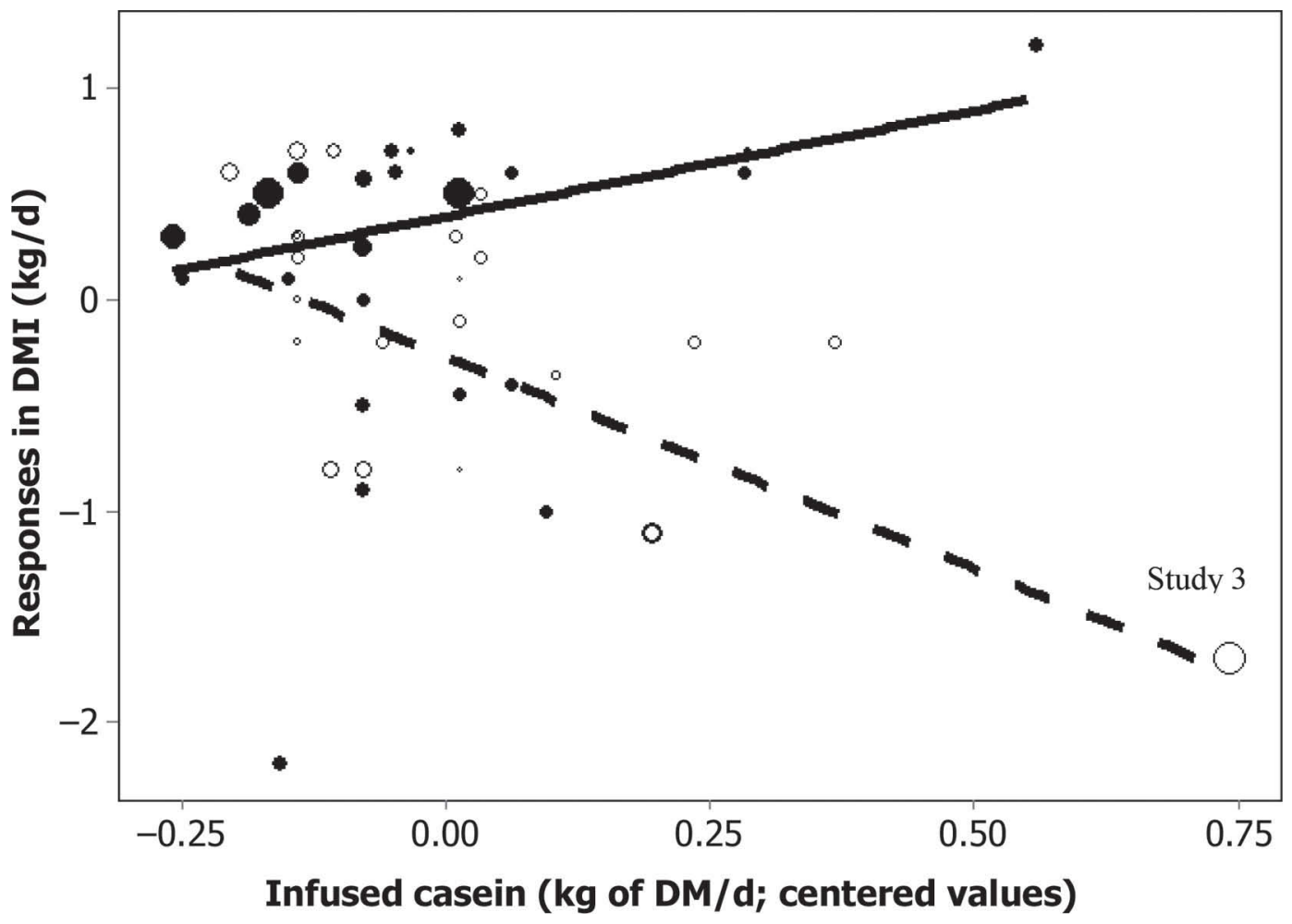

Figure 2. Graph showing the influence of the CN infusion rate ( $\mathrm{kg}$ of DM/d; centered values) on responses in DMI (kg/d) as a function of MP balance (meta-regression 2 in Table 4). Positive MP balance: straight bold line and closed circles; negative MP balance: dashed bold line and open circles. Each response in DMI is drawn proportional to its statistical weight (i.e., the inverse of the corresponding SE). Study 35 (refer to Table 1) is not shown for scaling reasons. 


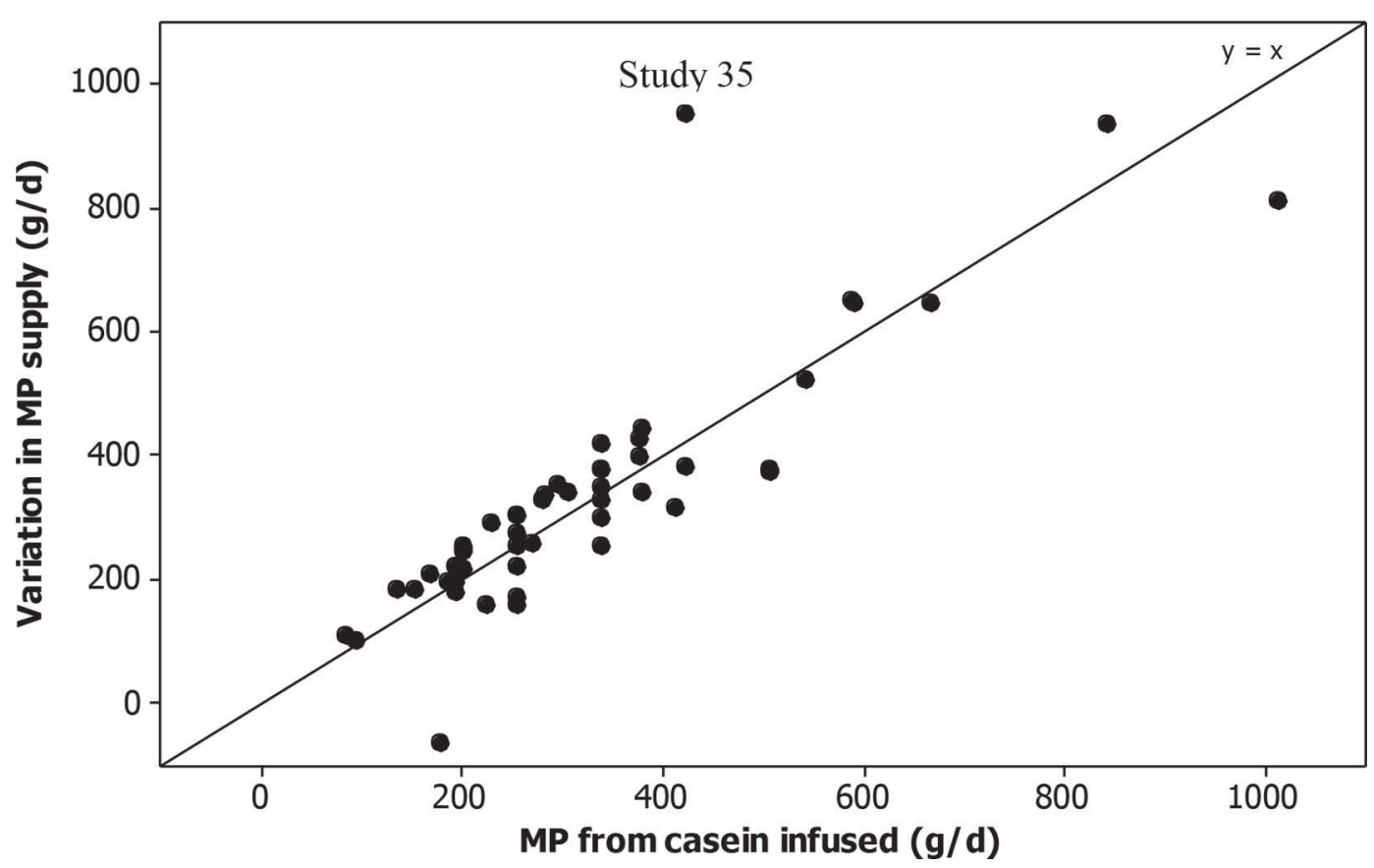

Figure 3. Graph showing the variation in MP supply (g of DM/d) against the amount of MP ( $\mathrm{g}$ of DM/d) infused by CN. The variation in MP supply was the difference in dietary MP supply (casein minus control treatments) plus the amount of MP infused by CN.

1997). Some AA might also regulate DMI by exerting a central feed intake signaling in dairy cows. Laeger et al. (2012) compared plasma and cerebrospinal fluid (CSF) concentrations of AA and other metabolites of dairy cows before and after a 50\% feed restriction. Plasma concentration of Ser, Thr, and Tyr did not change, but CSF concentration was reduced by 20,24 , and $31 \%$, respectively. The authors identified these AA as potential anorexigenic signals and concluded that the decrease in CSF concentration could be an adaptational response to improve appetite when the energy balance is negative. Jordi et al. (2013) administered isomolar doses of AA individually by gavage to rats and found that Arg, Lys, and Glu had a negative effect on food intake. The role of these AA in cows remains to be evaluated in further studies as abomasal or i.v. infusion of Arg (Vicini et al., 1988; Doepel and Lapierre, 2011) and Lys (Robinson et al., 2000) did not alter DMI. Laeger et al. (2012) reported similar CSF concentrations in Arg and Lys before and after feed restriction, but the drop in Glu $(-9 \%)$ did not reach significance.

Amino acids might also regulate DMI via the HOT concept (Allen and Piantoni, 2013; Allen, 2014). Deamination and oxidation of AA can increase when an oversupply in AA or an imbalance (deficiency of a limiting AA) is present. Most AA can be oxidized in the trichloroacetic acid cycle (via acetyl CoA or cycle intermediates) and generate ATP in the liver (Allen et al., 2009; Allen and Piantoni, 2013). Broad evi- dence in nonruminant species suggests that oxidation of metabolic fuels, including glucogenic AA, increases the liver energy charge (ATP concentration), which in turn decreases the discharge rate of the hepatic branch of the vagal nerve and signals brain's feeding centers to inhibit feed intake (Friedman, 1997). In dairy cows, the HOT concept might also apply and could explain the depression in feed intake observed during the peripartum period because of the "flood" of readily oxidizable nonesterified fatty acids to the liver (Allen et al., 2009). The HOT concept in dairy cows remains to be clearly demonstrated, but a recent study indicated that metabolic oxidative processes could be associated with satiety in dairy cows because time periods in which cows did not eat coincided with postprandial increases in whole-body net fat and carbohydrate oxidation rates (Derno et al., 2013).

If the HOT concept is correct, glucogenic AA should be oxidized at a greater extent when negative responses in DMI are observed (i.e., responses in DMI and in blood urea concentration should be negatively correlated). The correlation between responses in DMI and in blood urea concentration was negative only for cows in positive $\mathrm{MP}$ balance $(\mathrm{r}=-0.74 ; P=0.02$; data not shown). The influence of the $\mathrm{CN}$ infusion rate on responses in blood urea concentration was also analyzed. Responses in blood urea concentration averaged $0.59 \mathrm{mM}$ at mean $\mathrm{CN}$ infusion rate $(351 \mathrm{~g}$ of $\mathrm{DM} / \mathrm{d})$ and responses tended $(P=0.08)$ to differ for cows in 
negative and positive MP balance. For cows in negative MP balance, a 1 unit ( $\mathrm{kg}$ of $\mathrm{DM} / \mathrm{d})$ increase in the $\mathrm{CN}$ infusion rate from its mean increased $(P=0.03)$ further responses in blood urea concentration by $1.1 \mathrm{~m} M$, compared with cows not infused with CN. For cows in positive MP balance, the same increment in $\mathrm{CN}$ infusion rate increased $(P<0.001)$ further responses by 2.6 $\mathrm{m} M$, compared with cows not infused with $\mathrm{CN}$ (data not shown). Collectively, our observations for cows in positive MP balance suggest a link between the lack of response in MTPY, the increased synthesis of urea and the negative response in DMI. This link lends to support the HOT concept for the regulation of DMI in dairy cows when the supply of MP exceeds requirements for production and maintenance.

\section{Effect of Variation in DMI Responses}

Assuming that $\mathrm{CN}$ contains $92.7 \% \mathrm{CP}$ on a DM basis (NRC, 2001) and has a true intestinal protein digestibility of $100 \%$ (Huhtanen and Hristov, 2010), the amount of MP infused ranged from 84 to $1,012 \mathrm{~g} / \mathrm{d}$. Because cows on the CAS treatment did not eat the same amount of DM as cows on the control treatment (range -2.2 up to $4.4 \mathrm{~kg}$ of $\mathrm{DMI} / \mathrm{d}$; Table 1 ), this creates a deficit (or surplus) in estimated MP that should be deducted from (or added to) the amount of MP infused by $\mathrm{CN}$. In the data set, the variation in MP supply (or adjusted MP supply) ranged from -66 to $953 \mathrm{~g} / \mathrm{d}$ (y-axis in Figure 3). Although the correlation between the variation in MP supply and MP infused by $\mathrm{CN}$ was high $(\mathrm{r}=0.87)$, values were quite discordant in some studies (e.g., study 35 ). Therefore, future meta-analyses reviewing the effects of $\mathrm{CN}$ should test the influence of the variation in MP supply and not the rate of CN infusion itself, except for responses in DMI (due to a circular argument).

\section{CONCLUSIONS}

Overall, the average postruminal supply of $333 \mathrm{~g}$ of $\mathrm{CN} / \mathrm{d}$ (DM basis) tended to increase DMI by $0.18 \mathrm{~kg} / \mathrm{d}$ in cows fed ad libitum. However, a significant interaction was present between the infusion rate of $\mathrm{CN}$ and the initial MP balance (supply minus requirements). Casein infusion increased DMI by $0.39 \mathrm{~kg} / \mathrm{d}$ only in cows in negative MP balance. The rate of $\mathrm{CN}$ infusion had a positive influence on responses in DMI and in MTPY in MP-deficient diets, but had a negative influence on responses in DMI and no influence on responses in MTPY when MP was supplied in excess of requirements. The rate of $\mathrm{CN}$ infusion had a greater influence on responses in blood urea concentration when cows were in positive MP balance. Taken together, these re- sults suggest an increased deamination and oxidation of AA provided in excess of requirements and not directed toward MTPY. Notwithstanding other factors that could induce satiety (e.g., supply of anorexigenic AA), our results lend to support the HOT concept for the control of food intake. To test the influence of supplemental MP presented to the intestine, the amount of MP infused by CN should be corrected by the difference in estimated dietary MP supply.

\section{ACKNOWLEDGMENTS}

The authors gratefully thank Steve Méthot (Dairy and Swine Research and Development Centre; Sherbrooke, QC, Canada) and Robin White (National Animal Nutrition Program, University of Kentucky, Lexington, KY) for their statistical advice and contribution for this manuscript. Appreciation is also extended to Dairy Farmers of Canada (Ottawa) and Agriculture and AgriFood Canada (Ottawa) for the financial support and to Valacta (Sainte-Anne-de-Bellevue, Canada).

\section{REFERENCES}

Abramson, S. M., I. Bruckental, S. Zamwel, and A. Arieli. 2002. Effect of abomasally infused casein on post-ruminal digestibility of total non-structural carbohydrates and milk yield and composition in dairy cows. Anim. Sci. 74:347-355.

Allen, M. S. 2000. Effects of diet on short-term regulation of feed intake by lactating dairy cattle. J. Dairy Sci. 83:1598-1624.

Allen, M. S. 2014. Drives and limits to feed intake in ruminants. Anim. Prod. Sci. 54:1513-1524.

Allen, M. S., B. J. Bradford, and K. J. Harvatine. 2005. The cow as a model to study food intake regulation. Annu. Rev. Nutr. 25:523547.

Allen, M. S., B. J. Bradford, and M. Oba. 2009. Board-Invited Review: The hepatic oxidation theory of the control of feed intake and its application to ruminants. J. Anim. Sci. 87:3317-3334.

Allen, M. S., and P. Piantoni. 2013. Metabolic control of feed intake: Implications for metabolic disease of fresh cows. Vet. Clin. North Am. Food Anim. Pract. 29:279-297.

Appuhamy, J. A. D. R., A. B. Strathe, S. Jayasundara, C. WagnerRiddle, J. Dijkstra, J. France, and E. Kebreab. 2013. Anti-methanogenic effects of monensin in dairy and beef cattle: A metaanalysis. J. Dairy Sci. 96:5161-5173.

Baile, C. A., and J. M. Forbes. 1974. Control of feed intake and regulation of energy balance in ruminants. Physiol. Rev. 54:160-214.

Bougouin, A., J. A. D. R. N. Appuhamy, E. Kebreab, J. Dijkstra, R. P. Kwakkel, and J. France. 2014. Effects of phytase supplementation on phosphorus retention in broilers and layers: A meta-analysis. Poult. Sci. 93:1981-1992.

Broderick, G. A., A. E. Harper, and L. D. Satter. 1972. Response of lactating cows to feeding formaldehyde-treated casein at graded levels. Fed. Proc. 31:681. (Abstr.)

Cant, J. P., E. J. DePeters, and R. L. Baldwin. 1991. Effect of dietary fat and postruminal casein administration on milk composition of lactating dairy cows. J. Dairy Sci. 74:211-219.

Chamberlain, D. G., and J. M. Yeo. 2003. Effects of amino acids on milk production. Pages 367-387 in Amino Acids in Animal Nutrition. J. P. D'Mello, ed. CAB International, Wallingford, the Netherlands.

Choi, C. W., K. H. Kim, and S. H. Choi. 2013. Effects of abomasal infusions of casein, glucose or starch on milk production and blood metabolites in dairy cows. J. Agric. Life Sci. 47:81-89. 
Choung, J.-J., and D. G. Chamberlain. 1992a. The effect of the addition of cell-wall degrading enzymes at ensiling on the response to postruminal supplementation of protein in dairy cows receiving a silage based diet. J. Sci. Food Agric. 60:525-527.

Choung, J.-J., and D. G. Chamberlain. 1992b. Protein nutrition of dairy cows receiving grass silage diets. The effects of postruminal supplements of proteins and amino acids. J. Sci. Food Agric. 60:25-30

Choung, J.-J., and D. G. Chamberlain. 1992c. Protein nutrition of dairy cows receiving grass silage diets. Effects on silage intake and milk production of postruminal supplements of casein or soyaprotein isolate and the effects of intravenous infusions of a mixture of methionine, phenylalanine and tryptophan. J. Sci. Food Agric. $58: 307-314$.

Choung, J.-J., and D. G. Chamberlain. 1993a. The effects of abomasal infusions of casein or soya-bean-protein isolate on the milk production of dairy cows in mid-lactation. Br. J. Nutr. 69:103-115.

Choung, J.-J., and D. G. Chamberlain. 1993b. Effects of addition of lactic acid and postruminal supplementation with casein on the nutritive value of grass silage for milk production in dairy cows. Grass Forage Sci. 48:380-386.

Choung, J.-J., and D. G. Chamberlain. 1993c. Effects on milk yield and composition of intra-abomasal infusions of sodium caseinate, and enzymatic hydrolysate of casein or soya-protein isolate in dairy cows. J. Dairy Res. 60:133-138.

Choung, J.-J., and D. G. Chamberlain. 1995a. Effects of abomasal infusions of sodium caseinate and of casein hydrolysates varying in the relative proportions of peptides and free amino acids on milk production in dairy cows. J. Dairy Res. 62:423-429.

Choung, J.-J., and D. G. Chamberlain. 1995b. Effects of abomasal infusions of sodium caseinate, a hydrolysate of casein or a corresponding mixture of free amino acids on milk yield and composition in dairy cows. J. Dairy Res. 62:29-37.

Clark, J. H. 1975. Lactational responses to postruminal administration of proteins and amino acids. J. Dairy Sci. 58:1178-1197.

Clark, J. H., H. R. Spires, R. G. Derrig, and M. R. Bennink. 1977. Milk production, nitrogen utilization and glucose synthesis in lactating cows infused postruminally with sodium caseinate and glucose. J. Nutr. 107:631-644.

Cohick, W. S., J. L. Vicini, C. R. Staples, J. H. Clark, S. N. McCutcheon, and D. E. Bauman. 1986. Effects of intake and postruminal casein infusion on performance and concentrations of hormones in plasma of lactating cows. J. Dairy Sci. 69:3022-3031.

Derno, M., G. Nürnberg, P. Schön, A. Schwarm, M. Röntgen, H. M. Hammon, C. C. Metges, R. M. Bruckmaier, and B. Kuhla. 2013. Short-term feed intake is regulated by macronutrient oxidation in lactating Holstein cows. J. Dairy Sci. 96:971-980.

Derrig, R. G., J. H. Clark, and C. L. Davis. 1974. Effect of abomasal infusion of sodium caseinate on milk yield, nitrogen utilization and amino acid nutrition of the dairy cow. J. Nutr. 104:151-159.

Dhiman, T. R., C. Cadorniga, and L. D. Satter. 1993. Protein and energy supplementation of high alfalfa silage diets during early lactation. J. Dairy Sci. 76:1945-1959.

Doepel, L., and H. Lapierre. 2011. Deletion of arginine from an abomasal infusion of amino acids does not decrease milk protein yield in Holstein cows. J. Dairy Sci. 94:864-873.

Faverdin, P. 1999. The effect of nutrients on feed intake in ruminants. Proc. Nutr. Soc. 58:523-531.

Faverdin, P., D. M'hamed, and R. Vérité. 2003. Effects of metabolizable protein on intake and milk production of dairy cows independent of effects on ruminal digestion. Anim. Sci. 76:137-146.

Forbes, J. M. 1992. Metabolic aspects of satiety. Proc. Nutr. Soc. 51:13-19.

Friedman, M. I. 1997. An energy sensor for control of energy intake. Proc. Nutr. Soc. 56:41-50.

Griinari, J. M., M. A. McGuire, D. A. Dwyer, D. E. Bauman, and D. L. Palmquist. 1997. Role of insulin in the regulation of milk fat synthesis in dairy cows. J. Dairy Sci. 80:1076-1084.

Hedges, L. V., and I. Olkin. 1985. Statistical Methods for Meta-analysis. Academic Press, New York, NY.
Hristov, A. N., W. J. Price, and B. Shafii. 2004. A meta-analysis examining the relationship among dietary factors, dry matter intake, and milk and milk protein yield in dairy cows. J. Dairy Sci. $87: 2184-2196$.

Huhtanen, P., and A. N. Hristov. 2009. A meta-analysis of the effects of dietary protein concentration and degradability on milk protein yield and milk $\mathrm{N}$ efficiency in dairy cows. J. Dairy Sci. 92:3222-3232.

Huhtanen, P., and A. N. Hristov. 2010. Effects of energy and protein supply on milk protein yield responses in dairy cows. Pages 287-298 in Energy and Protein Metabolism and Nutrition. EAAP Publication No. 127. G. Matteo Crovetto, ed. Wageningen Academic Publishers, Wageningen, the Netherlands.

Huhtanen, P., H. O. Miettinen, and V. F. J. Toivonen. 1997. Effects of silage fermentation and post-ruminal casein supplementation in lactating dairy cows: 1-Diet digestion and milk production. J. Sci. Food Agric. 74:450-458.

Ingvartsen, K. L., and J. B. Andersen. 2000. Integration of metabolism and intake regulation: A review focusing on periparturient animals. J. Dairy Sci. 83:1573-1597.

Istasse, L., A. C. Brewer, and E. R. Ørskov. 1986. Effects of stage of lactation on the response of dairy cows to abomasal infusions of casein. Livest. Prod. Sci. 15:97-102.

Jordi, J., B. Herzog, S. M. R. Camargo, C. N. Boyle, T. A. Lutz, and F. Verrey. 2013. Specific amino acids inhibit food intake via the area postrema or vagal afferents. J. Physiol. 591:5611-5621.

Ketelaars, J. J. M. H., and B. J. Tolkamp. 1992. Toward a new theory of feed intake regulation in ruminants. 1. Causs of differences in voluntary feed intake: Critique of current views. Livest. Prod Sci. 30:269-296.

Khalili, H., and P. Huhtanen. 2002. Effect of casein infusion in the rumen, duodenum or both sites on factors affecting forage intake and performance of dairy cows fed red clover-grass silage. J. Dairy Sci. 85:909-918.

Konstantopoulos, S. 2011. Fixed effects and variance components estimation in three-level meta-analysis. Res. Synth. Methods 2:61-76.

Kuhara, T., A. Ikeda, A. Ohneda, and Y. Sasaki. 1991. Effects of intravenous infusion of 17 amino acids on the secretion of $\mathrm{GH}$, glucagon, and insulin in sheep. Am. J. Physiol. 260:E21-E26.

Laeger, T., S. Görs, C. C. Metges, and B. Kuhla. 2012. Effect of feed restriction on metabolites in cerebrospinal fluid and plasma of dairy cows. J. Dairy Sci. 95:1198-1208.

Larsen, M., H. Lapierre, and N. B. Kristensen. 2014. Abomasal protein infusion in postpartum transition dairy cows: Effect on performance and mammary metabolism. J. Dairy Sci. 97:5608-5622.

Lee, C., A. N. Hristov, T. W. Cassidy, K. S. Heyler, H. Lapierre, G. A. Varga, M. J. de Veth, R. A. Patton, and C. Parys. 2012. Rumenprotected lysine, methionine, and histidine increase milk protein yield in dairy cows fed a metabolizable protein-deficient diet. J. Dairy Sci. 95:6042-6056.

Mackle, T. R., D. A. Dwyer, and D. E. Bauman. 1999. Effects of branched-chain amino acids and sodium caseinate on milk protein concentration and yield from dairy cows. J. Dairy Sci. 82:161-171.

Martineau, R., D. Sauvant, D. R. Ouellet, C. Côrtes, J. Vernet, I. Ortigues-Marty, and H. Lapierre. 2011. Relation of net portal flux of nitrogen compounds with dietary characteristics in ruminants: A meta-analysis approach. J. Dairy Sci. 94:2986-3001.

Miettinen, H. O., and P. J. Huhtanen. 1997. Effects of silage fermentation and post-ruminal casein supplementation in lactating dairy cows: 2-Energy metabolites and plasma amino acids. J. Sci. Food Agric. 74:459-468.

NRC. 2001. Nutrient Requirements of Dairy Cattle. 7th rev. ed. National Academy Science, Washington, DC.

Ørskov, E. R., D. A. Grubb, and R. N. Kay. 1977. Effect of postruminal glucose or protein supplementation on milk yield and composition in Friesian cows in early lactation and negative energy balance. Br. J. Nutr. 38:397-405.

Patton, R. A., A. N. Hristov, C. Parys, and H. Lapierre. 2015. Relationships between circulating plasma concentrations and duodenal flows of essential amino acids in lactating cows. J. Dairy Sci. $98: 4707-4734$. 
R Development Core Team. 2008. R: A language and environment for statistical computing. $\mathrm{R}$ foundation for statistical computing. Vienna, Austria. www.R-project.org.

Relling, A. E., S. C. Loerch, and C. K. Reynolds. 2010. Plasma ghrelin and oxyntomodulin concentrations in lactating dairy cows receiving abomasal soybean oil, corn starch, and casein infusions. Domest. Anim. Endocrinol. 38:284-288.

Relling, A. E., and C. K. Reynolds. 2008. Abomasal infusion of casein, starch and soybean oil differentially affect plasma concentrations of gut peptides and feed intake in lactating dairy cows. Domest. Anim. Endocrinol. 35:35-45.

Robinson, P. H., W. Chalupa, C. J. Sniffen, W. E. Julien, H. Sato, T. Fujieda, T. Ueda, and H. Suzuki. 2000. Influence of abomasal infusion of high levels of lysine or methionine, or both, on ruminal fermentation, eating behavior, and performance of lactating dairy cows. J. Anim. Sci. 78:1067-1077.

Roche, J. R., D. Blache, J. K. Kay, D. R. Miller, A. J. Sheahan, and D. W. Miller. 2008. Neuroendocrine and physiological regulation of intake with particular reference to domesticated ruminant animals. Nutr. Res. Rev. 21:207-234.

Rogers, G. L., A. M. Bryant, K. E. Jury, and J. B. Hutton. 1979. Silage and dairy cow production. 3. Abomasal infusions of casein, methionine, and glucose, and milk yield and composition. N. Z. J. Agric. Res. 22:533-541.

Rogers, J. A., J. H. Clark, T. R. Drendel, and G. C. J. Fahey. 1984. Milk production and nitrogen utilization by dairy cows infused postruminally with sodium caseinate, soybean meal, or cottonseed meal. J. Dairy Sci. 67:1928-1935.

Røjen, B. A., N. B. Kristensen, M. Vestergaard, and M. Larsen. 2013. Effect of abomasal casein infusion on transport of urea-N from blood to gut in cows fed low $\mathrm{N}$ diet. Page 586 in 64th EAAP Annual Meeting. Book of Abstracts. Wageningen Academic Publishers, Wageningen, the Netherlands.

Schwab, C. G., C. K. Bozak, N. L. Whitehouse, and M. M. Mesbah. 1992. Amino acid limitation and flow to duodenum at four stages of lactation. 1. Sequence of lysine and methionine limitation. J. Dairy Sci. 75:3486-3502.

Seymour, W. M., C. E. Polan, and J. H. Herbein. 1990. Effects of dietary protein degradability and casein or amino acid infusions on production and plasma amino acids in dairy cows. J. Dairy Sci. $73: 735-748$.
Spechter, H. H. 1972. Postruminal casein infusion of urea-fed lactating cows. PhD Diss. University of Guelph, Guelph, Ontario, Canada.

St-Pierre, N. R. 2001. Invited review: Integrating quantitative findings from multiple studies using mixed model methodology. J. Dairy Sci. 84:741-755.

Vanhatalo, A., T. Varvikko, and P. Huhtanen. 2003a. Effects of casein and glucose on responses of cows fed diets based on restrictively fermented grass silage. J. Dairy Sci. 86:3260-3270.

Vanhatalo, A., T. Varvikko, and P. Huhtanen. 2003b. Effects of various glucogenic sources on production and metabolic responses of dairy cows fed grass silage-based diets. J. Dairy Sci. 86:3249-3259.

Vicini, J. L., J. H. Clark, W. L. Hurley, and J. M. Bahr. 1988. Effects of abomasal or intravenous administration of arginine on milk production, milk composition, and concentrations of somatotropin and insulin in plasma of dairy cows. J. Dairy Sci. 71:658-665.

Vicini, J. L., G. F. Hartnell, J. J. Veenhuizen, R. J. Collier, and L. Munyakazi. 1995. Effect of supplemental dietary fat or protein on the short-term milk production response to bovine somatotropin. J. Dairy Sci. 78:863-871.

Viechtbauer, W. 2010. Conducting meta-analyses in R with the metafor package. J. Stat. Softw. 36:1-48.

Viechtbauer, W. 2014. Mixed-model meta-regression. Accessed Mar. 6, 2015. http://stats.stackexchange.com/questions/116659/mixedmodel-meta-regression:accessed.

Viechtbauer, W. 2015. Package 'metafor' version 1.9-7. Accessed Jun. 23, 2015. http://cran.r-project.org/web/packages/metafor/ metafor.pdf.

Viechtbauer, W., and M. W.-L. Cheung. 2010. Outlier and influence diagnostics for meta-analysis. Res. Synth. Methods 1:112-125.

Vik-Mo, L., R. S. Emery, and J. T. Huber. 1974. Milk protein production in cows abomasally infused with casein or glucose. J. Dairy Sci. 57:869-877.

Wang, M. C., and B. J. Bushman. 2007. Integrating results through meta-analytic review using SAS software. Integrating results through meta-analytic review using SAS Software. SAS Institute, Cary NC.

Woods, S. C., T. A. Lutz, N. Geary, and W. Langhans. 2006. Pancreatic signals controlling food intake; insulin, glucagon and amylin. Phil. Trans. Royal Soc. B Biol. Sci. 361:1219-1235. 